\title{
UMA CIDADE ENTRE O RURAL E O URBANO: FÁBRICAS, FAZENDAS, TECELÕES E CAMPONESES EM MAGÉ ${ }^{1}$
}

\author{
Felipe Augusto dos Santos Ribeiro ${ }^{2}$
}

\begin{abstract}
Operário de Pau Grande / Precisou pedir socorro Estava sendo acuado / Como cassa por cachorro. A causa de tudo isso / Todos já sabem por que Norek mal chega aqui / Muda a regra de viver. Darcy a muito tempo / Nesta firma trabalhando 19 anos escrevendo / E seu serviço prestando. Sem ao menos avisado / Norek mandou chamar Você vai pra lavoura / Que tem outro em seu lugar. Veja seu moço se pode / Norek com sua pachorra Tirar um escriturário / E mandar para a lavoura. Sabedor de tudo isso / Guilherme o foi procurar Ou ele volta ao serviço / ou a fábrica vai parar. Norek daqui é chefe / Diz ele aqui sou a Lei Guilherme então responde / Isso amanhã eu verei. Guilherme é nosso amigo / Presidente do Sindicato Vendo o seu povo ofendido / dá um pulinho de gato. Vendo o oprimido / Resolve então agir Requerendo a Justiça / Essa não tardou em vir. Chegando Dr. Amil / Homem de capacidade Disse a Norek que o povo / Queria a sua amizade. O Norek não quis saber / Não quis trégua nem arrego Mandou chamar a Polícia / para o povo ficar com medo. O povo então revoltado / Resolverão então parar Vamos todos ao nosso posto / Mais não vamos trabalhar. A Polícia chegou armado / De metralhadora e fuzil Mais de vinte soldado / O que aqui nunca se viu. Os operários umildes / quietos sem nada falar Continuarão no seu posto / mas nada de trabalhar. Mas o Capitão Abílio / Então com doze soldado Para obrigar os operários / Até um foi espancado. Um Capitão do Exército / Chegou com nosso adevogado Apanhou eles em fragante / Que dali forão espulsado. Norek diz eu vou embora / Fiquei tão envergonhado Não pensei que uma coisinha / Daria tão mau resultado. Perguntou Dr. Amil: o Sr. não sabia / Então me responde esta Não sabe que uma faísca / Ensendeia uma floresta? (Autor desconhecido, s/d).
\end{abstract}

O escriturário Darcy Câmara era filho do tecelão, dirigente sindical e ex-vereador Gilberto Câmara, eleito em Magé pelo Partido Trabalhista Brasileiro (PTB) no ano de 1950, tendo também assumido a vereança em 1949, pelo mesmo partido, em decorrência da cassação dos comunistas no ano anterior.

\footnotetext{
${ }^{1}$ Artigo apresentado na X Reunião de Antropologia do Mercosul (RAM), realizada na cidade de Córdoba (Argentina) entre os dias 10 e 13 de julho de 2013, tendo sido debatido no Grupo de Trabalho: "Antropologia do Trabalho na cidade e no campo: desafios, conflitos, práticas, memórias e trajetórias".

${ }^{2}$ Universidade Estadual do Rio de Janeiro, Brasil.
} 
Gilberto Câmara nasceu na Gávea, cidade do Rio de Janeiro, no final do século XIX, tendo trabalhado como soldador na Fábrica de Tecidos Corcovado, localizada no bairro Jardim Botânico. Seu filho mais velho, Darcy, também nasceu no então Distrito Federal, em 1924. A família chegou a Magé pouco depois, em 1932, quando o patriarca começou a trabalhar na Fábrica Pau Grande, da Companhia América Fabril. Ao lado de sua casa, foi fundado o sindicato dos trabalhadores têxteis daquele distrito, do qual Gilberto Câmara se tornou presidente.

Assim como a maioria dos jovens do bairro, Darcy Câmara ingressou na fábrica aos 14 anos, tendo inclusive atuado como jogador, e mais tarde diretor, do Sport Club Pau Grande, mantido pela empresa têxtil. Na fábrica, não trabalhou muito tempo como tecelão, logo se tornou secretário-mestre da tecelagem, sendo responsável pela escrituração da produção por tear. Devido sua função "mais esclarecida", era constantemente procurado pelos demais operários para que conferisse se os seus bilhetes de pagamento estavam corretos.

Com a intensificação dessa prática, associada a sua entrada na militância comunista, Darcy Câmara tornou-se uma espécie de defensor velado dos trabalhadores têxteis. Quando percebia que o holerite ou o acerto de demissão estavam incorretos, ele orientava os operários a reclamar seus direitos junto à empresa e solicitar o apoio do sindicato para garantir o cumprimento da legislação trabalhista.

No início do ano de 1958, porém, o gerente da fábrica Thomaz Norek, de origem alemã, resolveu transferir Darcy Câmara de seu cargo, ao descobrir que ele "ajudava" os operários. Como uma espécie de castigo, designou que ele fosse trabalhar na lavoura, em terras da própria fábrica. A população indignou-se. O presidente do Sindicato, Guilherme Carvalho, consultou o advogado da entidade, o Dr. Jamil (ou Amil) Alves, e convocou uma greve, que perdurou por uma semana. Como resposta, o gerente da fábrica entrou em contato com o delegado de Magé, Abílio Gomes Vieira, o "capitão Abílio", que se dirigiu ao bairro com reforço policial, visando garantir a volta dos operários ao trabalho. Alguns deles, inclusive, foram espancados, despertando a ira da população (Imprensa Popular, 10/01/1958: 8).

Resultado: Darcy Câmara acabou sendo dispensado pela fábrica e a greve foi intensificada, tendo agora o sindicato apresentado novas reivindicações, tais como a melhoria no abastecimento de luz elétrica para o bairro, a viabilização de uma linha telefônica para a sede da entidade, a liberação de uma cota mensal de tecidos (um quilo) por operário a preço de custo, e o retorno de Darcy Câmara ao trabalho, podendo ele 
deixar o emprego (caso a medida não fosse cumprida ao seu contento) com direto a receber legalmente sua indenização trabalhista pelos dezenove anos dedicados à empresa. Para por fim ao impasse, foi convocada uma reunião entre os dirigentes sindicais e os diretores da fábrica, mediada pelo vice-governador Roberto Silveira; pelo diretor do jornal Última Hora, Luiz Fernando Bocayuva Cunha; pelo presidente do Sindicato de Santo Aleixo, Astério dos Santos; pelo agente do Instituto de Aposentados e Pensionistas da Indústria (IAPI) de Magé, José Barbosa Porto; entre outros. A direção da fábrica relutou, mas acabou cedendo às reivindicações dos trabalhadores, tendo porém que amargar Darcy Câmara, "homem estimadíssimo na localidade, que foi o primeiro operário a ser indenizado pela América Fabril desde a sua fundação" (Última Hora, 11/01/1958: 3).

Independente da veracidade relativa ao ineditismo desta indenização, o fato é que a greve de solidariedade à Darcy marcou decisivamente a memória operária - como podemos perceber no poema em estilo cordel que conta toda a história. Da mesma forma, essa experiência engendrou uma intensa mobilização política no município, tendo o "personagem estopim do conflito" tornado-se líder inconteste desses trabalhadores, o que aliás garantiu sua eleição à vereança poucos meses depois, pelo Partido Socialista Brasileiro (PSB).

Em sua trajetória política, Darcy Câmara não chegou a militar diretamente no Sindicato, mas apoiava o presidente da entidade e militante do PTB Guilherme Carvalho, posição também adotada pelos demais comunistas. Segundo o médico Irun Sant'Anna, o pai de Darcy, Gilberto Câmara, embora fosse do PTB, mantinha frequente diálogo com o Partido Comunista do Brasil (PCB). (Irun Sant’Anna, 06/04/2006).

Sem dúvida, esta greve evidenciou relações bastante interessantes que a Fábrica Pau Grande e seus trabalhadores mantinha tanto no mundo urbano, quanto no mundo rural. Primeiramente, destacamos que a noção de "roça como castigo" foi em parte assimilada pelos tecelões, tida como um rebaixamento e até uma afronta à dignidade operária. Por outro lado, a empresa possuía trabalhadores na indústria têxtil e também na sua "roça" (local para onde Darcy Câmara foi transferido).

E, ao que parece, essas relações se deram desde a fundação da fábrica, em 1878, nas terras da antiga Fazenda Pau Grande. 


\section{Fábrica-Fazenda}

Ao analisarem o início deste empreendimento no município, diversos estudos o classificam como uma "fábrica-fazenda", por ocasião de sua instalação, já que a fábrica destinava-se não apenas à produção industrial como também às explorações agrícolas (Weid; Bastos, 1986: 31 e Pimenta, 2012: 17).

Em 1892, a então Companhia de Fiação e Tecidos Pau Grande já havia comprado uma fábrica de tecidos no Distrito Federal (a Fábrica Cruzeiro), adotando uma nova política administrativa, dirigida à ampliação da produção têxtil e à expansão da empresa para o estabelecimento de fábricas na área urbana, modificando sua firma $\mathrm{e}$ transformando-se na Companhia América Fabril. No entanto, mesmo durante o período de maior projeção da companhia no cenário econômico do país, sobretudo na década de 1920, a categoria "fábrica-fazenda" continuava sendo levada em conta nas análises sobre a Fábrica Pau Grande.

Baseadas em trabalhos do antropólogo José Sérgio Leite Lopes, as pesquisadoras Elisabeth von der Weid e Ana Marta Rodrigues Bastos afirmaram que as características de "fábrica-fazenda" em Pau Grande assemelhavam-se muito às de outras vilas operárias pertencentes a indústrias têxteis surgidas no país na virada do século XIX para o XX e localizadas em regiões rurais. Inclusive, apontavam para a questão da localização e do isolamento da fábrica como determinantes nos rumos e alcance da política desenvolvida pela Companhia América Fabril, em termos de construção de moradias e instalação de infra-estrutura, aliadas ao estabelecimento de medidas de caráter social que visavam a permanência, o controle e a formação da força de trabalho (Lopes, 1979).

Na década de 1920 a fábrica-fazenda já se havia tornado quase auto-suficiente, constituindo uma comunidade fechada, isolada e com vida própria. As famílias se distribuíam na produção; mulheres e crianças na maior parte das tarefas têxteis, e os homens na lavoura, manutenção, nos trabalhos pesados ou de responsabilidade na fábrica, na administração e no controle. Esta situação permitiu a extrema estabilidade dos trabalhadores da fábrica-fazenda. O contingente em operação na época girava em torno de 550 operários e lavradores, e o número de registros encontrados até 1930 foi de 745. (...) Havia bastante intercâmbio de emprego entre as fábricas da região, e os operários que passavam por Pau Grande tinham boa acolhida nas outras fábricas. Mas, apesar dessa 'escola' sistemática de formação operária, os indivíduos nativos jamais perdiam seu caráter rural e, sempre que podiam, conseguiam local para a plantação de uma 'rocinha' particular. A maioria dos trabalhadores da fábrica, ao se aposentar, continuava na fazenda e cultivava canteiros nos fundos da casa ou em terrenos próximos, ou criava porcos ou galinhas. $\mathrm{O}$ fato de não sair do seu ambiente permitia a esses indivíduos manter sua origem e 
mentalidade rural, mesmo que sob intensa atividade e controle fabril. (Weid; Bastos, 1986: 164-165).

No município de Magé, a Companhia América Fabril foi pioneira no projeto “fábrica com vila operária", posto em prática desde os anos de 1910, enquanto que os investimentos das fábricas Andorinhas e Santo Aleixo ainda eram escassos nesse sentido, só ocorrendo de forma mais efetiva a partir das administrações Mattheis e Bezerra de Mello, respectivamente. ${ }^{3}$

$\mathrm{Na}$ realidade, as fábricas Meio da Serra, Pau Grande, Andorinhas e Santo Aleixo, em dado momento, construíram vilas para seus operários. A única exceção é a Fábrica Magé, no centro da cidade, certamente por estar localizada na região mais urbanizada do município. Também cabe assinalar a existência da vila operária da Fábrica de Pólvora Estrela, sob administração do então Ministério da Guerra, no bairro de Raiz da Serra, distrito de Inhomirim, que, apesar não ser objeto de análise nessa pesquisa, configura como uma informação interessante.

Essa combinação de fábrica com vila operária é bastante recorrente na bibliografia sobre industrialização e memória da classe trabalhadora, em diferentes campos de análise nas ciências sociais. Em diversos trabalhos, são citadas as vilas operárias construídas pelas fábricas de tecidos em Magé.

\begin{abstract}
Os estabelecimentos têxteis com moradias para trabalhadores foram uma característica do desenvolvimento industrial no interior do Estado do Rio de Janeiro. Exemplos são a 'Fábrica Esther' e a 'Fábrica Andorinhas', em Santo Aleixo, e o 'Cotonifício Levy Gasparian', estabelecido em Três Rios. A 'Fábrica de Tecidos e Fiação Pau Grande’, fundada em Magé em 1878, gerou um importante núcleo fabril - Pau Grande, que nos anos de 1950 e 1960 tornou-se famosa como o local onde Mané Garrincha nasceu e começou sua carreira. A 'Companhia América Fabril' foi proprietária da várias fábricas no Estado do Rio de Janeiro, todas fornecendo casas para seus operários. Além de Pau Grande, contava com outras fábricas com moradias. (Gunn; Correia, 2005: 29).
\end{abstract}

A principal referência nessas pesquisas é a obra do antropólogo José Sérgio Leite Lopes, autor de diversos trabalhos sobre o tema, que define o padrão "fábrica com vila operária" como o resultado de uma configuração específica da relação entre a força de trabalho industrial e o patronato, que se constitui em "uma situação onde a própria

\footnotetext{
${ }^{3}$ Há referências de que a Fábrica Santo Aleixo, já em meados do século XIX, provia alojamentos para os seus empregados, tendo as mulheres um compartimento em separado. Esta iniciativa se justificava devido à distância que "naturalmente forçava a moradia no próprio local da produção", pois mais da metade dos trabalhadores da fábrica era composta por colonos alemães oriundos de Petrópolis (Oliveira, 1992: 146-147). No entanto, não consideramos este tipo de alojamento como inserido no padrão fábrica-vila operária apontado por Lopes, 1979.
} 
fábrica é proprietária das casas em que moram seus operários e é promotora da vida social extra-fabril da localidade". (Lopes, 1988: 17).

Outro estudo interessante é o do geógrafo Márcio Piñon de Oliveira, que em um estudo sobre a Companhia Progresso Industrial do Brasil, mais conhecida por Fábrica de Tecidos Bangu, classificou três períodos distintos da empresa em sua relação com o espaço urbano: (1) “fábrica-fazenda”, constituído a partir da implantação da fábrica na Fazenda Bangu em 1889, quando apresentou uma estrutura verticalizada e complementada por uma produção agro-industrial; (2) "cidade-fábrica", que ganhou corpo durante a primeira grande expansão da produção têxtil da Companhia, nos anos que antecederam a Primeira Guerra Mundial, quando demandou um maior grau de urbanização, com a construção de vilas operárias, articulado à produção fabril; e (3) "fábrica da cidade", cuja configuração se iniciou em meados da década de 1930, com o processo de alienação patrimonial promovido pela companhia e a incorporação definitiva do subúrbio de Bangu à dinâmica do espaço metropolitano do Rio de Janeiro. (Oliveira, 2006).

Vale ressaltar que, desde a década de 1940, o próprio governo brasileiro começou a intensificar investimentos na construção de vilas operárias circunvizinhas às fábricas das empresas estatais. Nesse sentido, a construção da Usina Presidente Vargas, pela Companhia Siderúrgica Nacional (CSN), na localidade de Santo Antônio da Volta Redonda, no Vale do Paraíba, Estado do Rio de Janeiro, tornou-se um ícone.

Afastada dos grandes centros urbanos, Volta Redonda foi emancipada do município de Barra Mansa e se transformou na cidade símbolo do trabalhismo, a "Cidade do Aço". Na realidade, o município resumia-se a própria fábrica. Seu complexo fabril foi considerado uma cidade-industrial modelo para o país, habitada igualmente por operários-modelo, que formavam a "grande família siderúrgica".

Nesse ínterim, compreendemos os bairros industriais de Magé como um "caso particular do possível, no universo do padrão fábrica com vila operária" (Lopes, 1988: 20). Entretanto, para isso, faz-se necessário traçar certas distinções entre as vilas operárias do município.

Realmente, a vila operária de Pau Grande apresentava peculiaridades distintas das outras vilas de Magé, principalmente pelo fato de ser isolada e fechada em torno da fábrica, existindo inclusive uma cerca ao seu redor e um pórtico com guarda na entrada 
do bairro, onde eram registradas as entradas e saídas das pessoas. Chegou a ser considerada uma “cidade quase que independente do municipio" (Santos, 1957: 170). ${ }^{4}$

O próprio vereador e dirigente sindical Astério dos Santos, chegou a declarar, em outubro de 1959, no IV Congresso Fluminense de Municípios, que o bairro de Pau Grande seria um “Campo de Concentração” (CMM, n²1: 1v-2).

Anos antes, em 1953, o jornal comunista Imprensa Popular chamava o bairro de Pau Grande como um "feudo encravado na raiz da serra de Magé", explorando trabalhadores na fábrica e na lavoura (Imprensa Popular, 04/03/1953: 6). Aliás, o mesmo periódico, ao fazer a cobertura de uma eleição no sindicato dos tecelões de Pau Grande, informava que os trabalhadores votariam separados pelas seções existentes na fábrica, entre elas a seção da "Lavoura" (Imprensa Popular, 21/07/1954: 2). De qualquer forma, convém certa precaução ao investir no termo "comunidade fechada", pois ele denota aspectos semelhantes a uma "instituição total", o que não é o caso. No caso das fábricas de tecidos, particularmente, estudos apontam que a vida social cotidiana dos trabalhadores têxteis revela certa mobilidade, indisciplina e "liberdade", inclusive no próprio espaço fabril, concomitante ao controle patronal.

\begin{abstract}
Até mesmo dentro da fábrica, uma certa indisciplina e uma "cultura de oficina" podem desenvolver-se, parecendo quase indispensáveis para a boa gestão da produção. Além disso, graças à exploração autônoma de recursos oferecidos pela empresa - como a concessão de roçados operários ou de terrenos para cultivo, o uso das matas ao redor para fins materiais (lenha) ou para lazer (caça, especialmente de pássaros) -, esses operários, geralmente de origem camponesa, beneficiavam-se de condições de vida mais favoráveis do que poderíamos presumir, tendo em vista apenas os seus empregos industriais. Outras estruturas ainda estavam à sua disposição, como assistência médica, associações religiosas, grupos folclóricos, casa (...) e o clube de futebol (Lopes, 1992: 121).
\end{abstract}

Assim, os trabalhadores da Fábrica Pau Grande apresentavam um perfil de difícil definição: são tecelões e também lavradores. Porém, preliminarmente, com base em estudos de outras regiões, observamos que esses trabalhadores não se encaixam, por exemplo, na tipificação de Worker-Peasants (colono-operário), tal como utilizado na pesquisa de Giralda Seyferth, pois não se caracterizam como operários de origem camponesa que trabalham na fábrica e possuem pequena propriedade de terra na área rural, onde também trabalham (Seyferth, 1987).

\footnotetext{
${ }^{4}$ De fato, a questão do isolamento é bastante peculiar para a Fábrica Pau Grande em relação as outras fábricas de tecidos do município. Aspecto semelhante foi observado no estudo sobre a Companhia de Tecidos Paulista, localizada em Pernambuco. (Lopes, 1988: 16).
} 
Nem tampouco, esses trabalhadores da Fábrica Pau Grande se enquadravam no perfil jurídico adotado junto à indústria açucareira, que de forma semelhante possuía funcionários na lavoura de cana-de-açúcar e na usina, sendo aqueles equiparados aos trabalhadores da indústria, o que normalmente não ocorria com os demais trabalhadores rurais (Welch, 2010: 299). Há inclusive registros acerca de cortadores de cana da cidade de Assis, em São Paulo, que obtiveram ganho de causa na Justiça do Trabalho, em 1958, tendo direito ao dissídio coletivo, à indenização e à estabilidade no emprego, nos mesmos moldes em eram previstos para os trabalhadores da Usina Nova América, que mantinha uma fazenda homônima, onde trabalhava os cortadores, como parte de um mesmo complexo industrial açucareiro (Silva, 2013).

Alguns estudos destacaram que a Fábrica Pau Grande, devido as suas necessidades de abastecimento com energia hidráulica, passou a adquirir novas terras circunvizinhas, o que acabou potencializando investimentos agrícolas por parte da empresa, a fim de fixar seus limites territoriais. Dessa forma, além das casas da vila operária junto à fábrica, foram construídas outras, mais esparsas, como demarcação de sua propriedade. Chegou-se até a construir uma pequena estrada de ferro, passando pela fazenda e pela fábrica até o ramal ferroviário de Raiz da Serra. Quanto aos trabalhadores da "roça", eles eram basicamente homens, enquanto que suas esposas e seus filhos, na maioria das vezes, eram empregados como tecelões. Os que plantavam tinham que obrigatoriamente repassar um terço de sua produção à empresa, que seria comercializado no seu armazém junto à vila operária (Alentejano, 2002).

No que tange à possibilidade de origem camponesa dos tecelões de Magé, há realmente vários registros de que apontam nesse sentido, sobretudo após o avanço das políticas sociais (extrafabris) das indústrias têxteis locais pós-1930. A estrutura social organizada pelas empresas (com a consolidação do sistema fábrica-vila operária), associada ao consequente aumento na oferta de empregos, provocou uma expressiva migração para o município, conforme publicado no jornal $O$ Fluminense, em 1945: "Vagas para operários: o Serviço de Colonização e Trabalho dispõe de vagas para pedreiros, carpinteiros e operários em fábricas de tecidos no município de Magé” (O Fluminense, 27/07/1945: 1). Nesse ínterim, verificamos uma grande entrada de mineiros, capixabas e nordestinos de um modo geral, além de fluminenses de outros municípios, em sua grande maioria oriunda de áreas rurais (um novo fluxo migratório em direção à Magé adquiriu força no início da década de 1960, este já motivado pelas notícias de possíveis desapropriações de terra no município). 
Desses migrantes, muitos operários faziam questão de manter uma "rocinha" em seu quintal, de forma particular, cultivada no período de atividade extrafabril, embora isso não os caracterizasse, em tese, como um "Weaver-Peasants", pois não ocupavam as duas funções laborais simultaneamente, em um misto de trabalhador têxtil-trabalhador rural.

Durante a nossa pesquisa, encontramos registros de tecelões de Magé que acabaram rumando para o campo, por diversos motivos. O caso de Manoel Ferreira de Lima, por exemplo, é bastante ilustrativo: um migrante nordestino, ex-tecelão em Magé, atuante no sindicato da categoria, membro da igreja batista e militante do PCB, que mais tarde tornou-se líder camponês no município (fundando e presidindo associações e sindicatos rurais) e no território fluminense, tendo ocupado a presidência da Federação das Associações de Lavradores do Estado do Rio de Janeiro (FALERJ) e participado da fundação da Confederação Nacional dos Trabalhadores na Agricultura (CONTAG).

Outro interessante episódio foi noticiado pelo jornal Imprensa Popular, em 1954, quando ex-operários da Companhia Santo Amaro, proprietária da Fábrica Magé (antiga Companhia Mageense), que havia entrado em processo de falência, lançaram mão de um terreno abandonado circunvizinho para dedicar-se a lavoura, tendo inclusive enfrentado tentativas de despejo (Imprensa Popular, 22/05/1954: 2).

Entretanto, faz necessário analisar mais amiúde a Fábrica Pau Grande, sua organização e sua distribuição de trabalhadores, especialmente se havia mobilidade significativa entre seções, tendo tecelões que foram para a "roça" e vice-versa. Igualmente, é preciso comparar as características desta empresa com as demais fábricas de tecidos de Magé para compreender o que é genérico e específico.

\section{Rural no Urbano e Vice-Versa}

Embora as fábricas de tecidos denotassem um perfil urbano para o município, as características "mais emocionais" sobre Magé normalmente relacionadas a uma "forma de vida campestre", talvez até por ser uma pequena cidade, situada bastante próxima a então capital do país, tendo o bucólico, a tranquilidade e a valorização da natureza combinado com a "urbanidade" das indústrias têxteis. ${ }^{5}$

\footnotetext{
${ }^{5}$ Sobre o estudo das representações do rural e do urbano (Williams, 2011).
} 
Como exemplo, podemos citar a memória construída em torno da Fábrica Santo Aleixo, que ilustra bem o que pretendemos abordar.

(...) Tudo passou, meu filho. Tudo. Você um dia vai ser pai e vai também descobrir como são difíceis certos momentos na vida de um homem. Parece que nada dá certo, provocando um desespero interminável. Mas agora, não. Papai foi nomeado gerente da Fábrica de Santo Aleixo. Nunca mais vai faltar nada nos seus sapatinhos na noite de Natal. (...) Não chore, meu filho. Nós vamos ter uma casa muito grande. Um rio de verdade passa bem atrás. Grandes árvores e tantas, que serão só suas. Você pode fazer, armar balanços (Vasconcelos, 1975: 187-188).

Foi recebendo esta notícia que o menino Zezé, personagem principal do livro $\mathrm{Meu}$ Pé de Laranja Lima, sentiu o retorno de uma "nuvem de paz" sobre sua família após severo período de desemprego. A obra, considerada o maior sucesso editorial de José Mauro de Vasconcelos, foi publicada pela primeira vez em 1968, chegando a ser traduzida para diversas línguas. Nela, o autor lança mão de sua própria experiência de vida para discutir as dores e as angústias da infância diante das constantes mudanças de vida provocada pelos adultos.

José Mauro de Vasconcelos nasceu no bairro de Bangu, cidade do Rio de Janeiro, onde funcionava uma importante fábrica de tecidos, a Companhia Progresso Industrial do Brasil. Aliás, grande parte das histórias contadas em seu livro remete à referida fábrica.

Para o personagem Zezé, a fábrica trazia más lembranças: "Não gostava dela. (...) A Fábrica era um dragão que todo dia comia gente e de noite vomitava o pessoal muito cansado. Não gostava ainda porque Mister Scottfield fizera aquilo com Papai..." (Vasconcelos, 1975: 63-64). O pai do protagonista havia discutido com um dos diretores da fábrica e, por isso, acabou sendo demitido, desencadeando um período de muitas dificuldades para a família. Toda essa angústia, porém, foi minimizada após seu pai conseguir um emprego na Fábrica Santo Aleixo, no município de Magé.

No contexto da obra, especificamente, esta outra fábrica configurou como uma espécie de "porto seguro" para a família de Zezé, sendo inclusive valorizada a beleza do lugar onde ela estava localizada, com "rios de verdade" e "grandes árvores".

Nesse sentido, tornou-se bastante peculiar esta representação acerca da Fábrica Santo Aleixo, sobretudo na medida em que ela se aproxima de diversas outras caracterizações construídas por meio da memória operária e de publicações locais, que passaremos a analisar mais detidamente.

A primeira delas refere-se ao livro Magé durante o Segundo Império e os primeiros tempos da República: a história de uma abnegada mulher (Fernandes, 1962), 
que conta a trajetória de Francisca D’Azevedo Paiva, poetisa, filha do capitão Gabriel de Azevedo Maia Lage, fazendeiro e chefe político local. Após um longo período de fausto e riqueza em sua família, "Chiquinha", como era conhecida a protagonista, passou enfrentar diversos dissabores, motivados pela dificuldade financeira. ${ }^{6}$

Assim, Francisca teve que sair do convívio com seu pai, na fazenda, para acompanhar o marido, José Alexandre, recém contratado pela Fábrica de Tecidos Santo Aleixo. Uma de suas filhas, Zoraida, mais tarde casou-se com um pequeno comerciante local, Emygdio Fernandes, um dos alvos da primeira mobilização operária que se tem notícia na região: a "Greve do Pano" 7 .

Santo Aleixo sempre fora habitado por gente pacata e de costumes morigerados. Centro essencialmente fabril, pois não havia pessoas afortunadas, nem tampouco a chamada classe burguesa, tão odiada pelos que professam o comunismo. Comerciantes e operários viviam em perfeita harmonia, um dependendo do outro. Mas aquela vida boa e pacata, fora quebrada com o advento do regime comunista da Rússia. Para ali convergiam os chamados delegados dos operários, que outra coisa não eram senão meros agitadores. Promoviam comícios de rua, e nas pregações revolucionárias pregavam o amor livre, a dissolução da família e a divisão de latifúndios. (...) Ao cair da tarde, enorme massa se postava diante da agência postal, na ânsia de adquirir números dos jornais abertamente comunistas (...). E naquele dia aprazado, os operários a um sinal convencionado (...) pararam as máquinas e entraram a praticar desatinos. O plano era por demais diabólico (...). Instalaram o 'Soviet' local, e em substituição a bandeira brasileira, hastearam a bandeira vermelha, com o dístico: 'Viva Lenine'. A seguir, os amotinados saíram em delírio pelas ruas precedidos pela Banda de Música, entoando a Internacional de Moscou (Fernandes, 1962: 54-57).

Para Antônio de Paiva Fernandes, autor da obra, esse movimento foi um "plano diabólico de amotinados", sem, no entanto, deixar de descrevê-lo como fabuloso, mesmo que noutra perspectiva. Publicada em 1962, a obra deste escritor mageense é permeada por uma forte posição anticomunista, típica da época em que foi concebida, mas que, ao mesmo tempo, apresenta a "Greve do Pano" de forma bastante apoteótica. Nota-se que seu discurso realça Santo Aleixo como um lugar "pacato e morigerado", onde patrões e operários vivam em "perfeita harmonia"; harmonia essa quebrada única e exclusivamente pelos "agitadores comunistas", aqueles que "quebram" o contrato, segundo ele, estabelecido.

\footnotetext{
${ }^{6}$ A referida obra atribui o declínio agrícola do município de Magé, no final do século XIX, como já dissemos, aos reflexos da abolição da escravatura e ao episódio conhecido como "Horrores de Magé", no contexto da Revolta da Armada, em 1893-94.

${ }^{7}$ A greve de 1918 foi assim foi denominada pelos santoaleixenses mais antigos, conforme entrevistas com os ex-operários Waldomiro Pinto Carneiro e Benedito Queiroz Vieira, hoje falecidos, realizadas pelo Grupo Centenário, por ocasião da comemoração dos cem anos de criação do distrito de Santo Aleixo, em 1992. Acervo de Ademir Calixto Oliveira. A greve também foi noticiada por jornais do Rio de Janeiro (A Noite, 22/11/1918: 3).
} 
Outra representação interessante foi uma crônica publicada em 1963, numa revista comemorativa aos cinquenta anos de fundação do Guarany Futebol Clube, entidade mantida pela Fábrica Santo Aleixo. Organizada pela diretoria do clube, a revista trazia na matéria intitulada $O$ Tradicional Guarany $x$ Andorinhas a mística que envolvia o clássico entre os dois times operários, sendo este último mantido pela Fábrica Andorinhas, também localizada no distrito de Santo Aleixo.

\begin{abstract}
Num pequeno ponto do território mageense, situa-se Santo Aleixo. Sua localização, ao pé Serra dos Órgãos, fornece-lhe encantos naturais de realce profundamente poéticos. À tarde, quando o crepúsculo desce a crista da montanha e a natureza se recolhe para entoar o cântico da noite, as sombras se estendem pelo leito deste amado e maravilhoso vale e o silêncio torna mais solene a voz melancólica do cair das suas cachoeiras. Suas paisagens, muitas das quais ainda desconhecidas, proporcionam inspirações de gratidão ao nosso Senhor, por ter com sua Divina Graça, sido tão generoso em nos oferecer tão simpático e atraente lugarejo. E tudo isso, nos dá um aspecto de que seu povo vive numa verdadeira paz entre seus irmãos. No entretanto, existe um dia em que tal paz e a comunhão de verdadeira amizade entre seus filhos é ligeiramente estremecida. Dizemos ligeiramente pelo fato de tal estremecimento não atingir a solidez em que foi firmado o alicerce desta amizade. Sim, meus amigos, quando o Campeonato Mageense de Futebol assinala em sua tabela o clássico de maior envergadura municipal: Guarany Futebol Clube $\mathrm{x}$ Andorinhas Futebol Clube, os habitantes desta tão exaltada cidade experimentam modificações sensíveis em sua personalidade, a qual é sobreposta pelo sentimento de amor pelas cores do seu clube. Uma semana antes do jogo, os comentários são inúmeros (...) Os de cima evitam mesmo de vir cá embaixo. Os daqui, igualmente, se sentem desambientados em ir lá em cima. E é nesse clima de verdadeira tensão que chega o dia em que no campo os times e as torcidas se defrontam (...) Após o jogo, ou melhor, passado então mais ou menos uma semana, as torcidas vão assumindo novamente a sua forma. E a calma volta a reinar em Santo Aleixo. Seus filhos vão naturalmente voltando a um mesmo convívio. As hostilidades desaparecem, dando lugar a um outro sentimento de maior envergadura: o do trabalho e da ajuda desinteressada ao próximo, seja do lado de lá ou do lado de cá (Guarany, 1963: 15 e 17).
\end{abstract}

Percebemos que há algo em comum entre esses dois discursos, quando Santo Aleixo é apresentado como um lugar de "paz, amizade e comunhão", onde somente situações extraordinárias, normalmente movidas por paixões fugazes, conseguem "ligeiramente" estremecê-lo. No primeiro, é a paixão comunista; no outro a paixão pelo time operário.

A propósito, as representações evidenciadas nos discursos acima também encontram eco nos depoimentos de alguns ex-operários, configurando como um fator de forte coesão no seio dos trabalhadores têxteis locais.

(...) Santo Aleixo era um lugar animado, um lugar que gerava muito emprego. As fábricas geravam muito emprego na época. (...) Tudo ali em Santo Aleixo e Andorinhas girava em torno da economia das duas fábricas né. Era emprego para as crianças, assim... Entrava com quatorze anos e trabalha até aposentar... Muita gente em Santo Aleixo e Andorinhas aposentou novo porque entrou trabalhando ali aos 
quatorze anos. (...) As pessoas vinham de Magé trabalhar, de outros lugares... (...) Havia-se muito respeito, era muito bom. Você não via ninguém saindo, falando bandalheira no meio da rua. Você ia num clube, num baile, era muito respeitado, ninguém te faltava com respeito. Era uma época muito boa (...). (Jorge Carloto Lima, 22/03/2008).

(...) Tinha o cinema, que tinha a primeira seção às 6 horas, e a segunda às 8 horas. Tinha também o refeitório do lado, onde fazia tarde dançante. Então a gente ia pra tarde dançante, e depois a gente ia pro cinema. No domingo e qualquer feriado que dava, que tivesse um filme bom, a gente assistia. A época era muito boa (...). (Maria Oneida Péclat, 18/01/2007).

Percebe-se que a centralidade do trabalho fabril fundamentou as lembranças e, por conseguinte, a identidade coletiva de toda uma geração, cuja vivência de uma época aparece como um "tempo áureo", que não existe mais, no qual havia solidariedade, respeito, amor e onde as pessoas que "trabalhavam muito". Este aspecto, ao que parece, também foi relevante na construção da memória dos demais bairros operários mageenses.

Gostaríamos de destacar igualmente o quanto as belezas naturais do lugar são evocadas nas narrativas, semelhantes inclusive ao do trecho citado de Meu Pé de Laranja Lima. Cercado por belas serras e cachoeiras, Magé de fato despertava o interesse tanto de turistas e grupo de escoteiros, quanto da própria população local, que dispunha de uma forma de lazer "natural e gratuita". Porém, advertimos que este aspecto não deve ser interpretado, pura e simplesmente, como uma "mentalidade campestre" dos trabalhadores mageenses.

Ao contrário das famílias camponesas, que inculcam desde muito cedo nos filhos o senso de responsabilidade e projeto para tudo o que diz respeito à exploração agrícola e ao trabalho que ela requer, as famílias operárias manifestam de maneira geral uma grande permissividade quanto ao lazer de suas crianças, como que compensando antecipadamente a fatalidade do excesso de trabalho industrial. E nas fábricas situadas no meio rural, esses divertimentos juvenis concentram-se particularmente em torno da utilização dos "recursos naturais" oferecidos pela empresa (Lopes, 1992: 123).

Em um interessante artigo sobre o jogador de futebol Garrincha, nascido em Pau Grande e ex-operário da fábrica, o sociólogo Sylvain Maresca e o antropólogo José Sérgio Leite Lopes apresentaram um estudo etnográfico sobre craque a partir do seu funeral e da repercussão de sua morte na imprensa. Neste trabalho, há uma discussão essencial para a nossa pesquisa que trata justamente da caracterização de Garrincha como sendo um camponês, pois para alguns jornalistas esportivos, esta era a 
justificativa para a originalidade do seu estilo de jogo (livre e descompromissado, embora alegre e admirável), bem como para o seu comportamento "não profissional". Conforme bem observado pelos autores, essas caracterizações evidenciavam sobremaneira o antagonismo camponês=amador)/operário=profissional (diria também rural/urbano) no imaginário dos escritores analisados, "apagando a vila operária [onde Garrincha viveu] na imprecisão de um fundo longínquo paisagem rural” (Lopes, 1992: 126).

(...) 'Garrincha é uma árvore. Ele pertence à natureza'. Na verdade, talvez fosse mais adequado dizer que Garrincha pertencia a uma espécie determinada - e em via de extinção - do gênero humano brasileiro. Ele nasceu, cresceu e morreu homem da terra, ao mesmo tempo inocente e astuto como seus iguais, e, como eles, também, estrangeiro aos valores e formas de comportamento da cultura urbana. Pouco importa que meros 90 quilômetros separem Pau Grande do Rio de Janeiro - antes da irrupção da TV, a distância cultural entre os dois lugares era intransponível. (Weiss: 130. Apud: Lopes: 1992: 130 - anexo 1).

\section{Conclusão}

Após esta breve exposição, portanto, reiteramos a importância de uma análise histórica detalhada, como em qualquer outra pesquisa, mas sobretudo quando se trata de questões tão complexas como as imbricações entre o rural e o urbano. Sem dúvida, torna-se imperioso atentar não apenas para o fenômeno social em si, como também para as visões e os referenciais que se apresentam tanto nas fontes, quanto na bibliografia. Como no caso de Garrincha, ainda que a sua imagem não correspondesse à de um operário, sua vida foi construída de fato em torno de uma fábrica têxtil, tendo nascido em uma família que habitava uma vila operária em meio rural.

\section{Referências}

ALENTEJANO, Paulo [et.al]. Assentamento Cachoeira Grande: Magé. In: Conhecendo assentamentos rurais no Rio de Janeiro. Rio de Janeiro: CPDA/UFRRJ, 2002. pp.35-76.

FERNANDES, Antônio de Paiva. Magé durante o Segundo Império e os primeiros tempos da República: a história de uma abnegada mulher. Rio de Janeiro: s/ed, 1962.

GUARANY FUTEBOL CLUBE. Revista comemorativa do jubileu de ouro (1913/1963). Santo Aleixo, Magé/RJ: 1963.

GUNN, Philip; CORREIA, Telma de Barros. A industrialização brasileira e a dimensão geográfica dos estabelecimentos industriais. Revista Brasileira de Estudos Urbanos e Regionais. v.7. n.1. maio/2005. 
LOPES, José Sérgio Leite. Fábrica e vila operária: considerações sobre uma forma de servidão burguesa. In: [et.al]. Mudança social no Nordeste: a reprodução da subordinação. Rio de Janeiro: Paz e Terra, 1979.

Sobre os trabalhadores da grande indústria na pequena cidade: crítica e resgate da 'Crise do Brasil Arcaico'. In: [org.] Cultura \& identidade operária: aspectos da cultura da classe trabalhadora. Rio de Janeiro: Marco Zero; UFRJ, 1987. pp.147-170.

A Tecelagem dos Conflitos de Classe na Cidade das Chaminés. Brasília, DF: Editora UNB; Marco Zero, 1988.

\& MARESCA, Sylvain. A Morte da "Alegria do Povo". Rio de Janeiro: Revista Brasileira de Ciências Sociais, 1992. v. 20.

OLIVEIRA, Geraldo de Beauclair Mendes de. Raízes da indústria no Brasil: a pré-indústria fluminense, 1808-1860. Rio de Janeiro: Studio F\&S Editora, 1992.

OLIVEIRA, Márcio Piñon de. Quando a fábrica cria o bairro: estratégias do capital industrial e produção do espaço metropolitano no Rio de Janeiro. Revista Electrónica de Geografia Y Ciências Sociales. Barcelona: Universidade de Barcelona. v.10. n.218. ago/2006. Disponível em <http://www.ub.es/geocrit/sn/sn-218-51.htm>. Acessado em 25 de abril de 2009.

PIMENTA, Ricardo Medeiros. Retalhos de Memórias: Trabalho e Identidade nas Falas de Operários Têxteis do Rio de Janeiro. Rio de Janeiro: dissertação (Memória Social) UNIRIO, 2006.

Retalhos de Memória: Lembranças de Operários Têxteis Sobre Identidade e Trabalho. Jundiaí, SP: Paco Editorial, 2012.

RIBEIRO, Felipe Augusto dos Santos. Operários à tribuna: vereadores comunistas e trabalhadores têxteis de Magé (1951-1964). São Gonçalo: dissertação (História Social) FFPUERJ, 2009.

SANTOS, Renato Peixoto dos. Magé: Terra do Dedo de Deus. Rio de Janeiro: IBGE, 1957.

SEYFERTH, Giralda. Aspectos da proletarização do campesinato no Vale do Itajaí (SC). In: LOPES, 1987: 103-120.

SILVA, Fernando Teixeira da. "Justiça de Classe": tribunais, trabalhadores rurais e memória. [digitalizado, no prelo], 2013. 40p.

VASCONCELOS, José Mauro de. Meu pé de laranja lima. São Paulo: Melhoramentos, 1975.

WEID, Elisabeth von der; BASTOS, Ana Marta Rodrigues. O Fio da Meada: Estratégia e Expansão de uma indústria têxtil: Companhia América Fabril 1878/1930. Rio de Janeiro: Fundação Casa de Rui Barbosa, 1986.

WEISS, L. \& CASTELO, J. O último inocente: Garrincha morreu sem entender o mundo, nem o futebol. In: Isto É. Rio de Janeiro: 26/01/1983. Apud: Lopes: 1992, 130 [anexo 1].

WELCH, Clifford Andrew. A semente foi plantada: as raízes paulistas do movimento sindical camponês no Brasil (1924-1964). São Paulo: Expressão Popular, 2010. 
WILLIAMS, Raymond. O Campo e a cidade na história e na literatura. São Paulo: Companhia das Letras, 2011.

\section{Arquivos públicos}

CMM (Câmara Municipal de Magé). Livro de Atas n.21 (10/11/1959 a 29/11/1960).

\section{Arquivos particulares}

Autor desconhecido. s/d. Cedido ao autor deste artigo, em cópia reprográfica, por Gecília Câmara, irmã de Darcy Câmara, no ano de 2009. Acervo da família. Optou-se por manter a grafia original.

\section{Periódicos}

Imprensa Popular

Última Hora

O Fluminense

A Noite

\section{Entrevistas}

Irun Sant'Anna (médico e militante comunista): concedida a Felipe Augusto dos Santos Ribeiro, em 06 de abril de 2006.

Jorge Carloto Lima (ex-operário): concedida a Joana Lima Figueiredo em 22/03/2008.

Maria Oneida Péclat (ex-operária): concedida a Juçara da Silva Barbosa de Mello em $18 / 01 / 2007$

Recebido: $27 / 07 / 2013$

Aprovado: 16/08/2013 